\title{
Issues and Challenges of Applying E-Learning: The Case of One State Islamic University
}

\section{SHOHIBUL KAHFI ALAM PUTRA ${ }^{1}$, SOFENDI ${ }^{2}$, AND MARGARETHA DINAR SITINJAK ${ }^{3}$}

\begin{abstract}
Indonesia is now overwhelmed with the issues and challenges in utilizing e-learning in many state Islamic universities. Moreover, this situation became worst when the COVID-19 influenced the teaching and learning process exponentially. This mixed methods study aimed to explore primary issues and challenges of using e-learning faced by one Indonesian state Islamic university in South Sumatra Province, Indonesia, and the solutions to overcome those hindrances. Three primary participants included students, academic staff, and faculty boards contributed to this study. The data obtained from closed and open-ended questionnaires and interviews were analyzed by using a thematic analysis. The findings revealed five primary issues and challenges of using e-learning such as infrastructure, digital content, individual constraints, technical support, and financial support.
\end{abstract}

\author{
Keywords \\ Challenges; e-learning; \\ Indonesian state Islamic \\ university; issues \\ Article History \\ Received 11 July 2021 \\ Accepted 30 January 2022 \\ How to Cite \\ Putra, S. K. A., Sofendi, \& \\ Sitinjak, M. D. (2022). \\ Issues and challenges of \\ applying e-learning: The case \\ of one state Islamic \\ university. | IRJE |Indonesian \\ Research Journal in Education|, \\ 6(1), 6 - 27. https://doi.org/ \\ 10.22437/irje.v6i1.13951
}

Faculty of Teacher Training and Education, Universitas Sriwijaya, Palembang, Indonesia; shohibulkahfiofficial@gmail.com

2 Faculty of Teacher Training and Education, Universitas Sriwijaya, Palembang, Indonesia.

3 Faculty of Teacher Training and Education, Universitas Sriwijaya, Palembang, Indonesia. 


\section{IRJE | Indonesian Research Journal in Education | \\ | Vol. 6| No. 1|June | Year 2022 |}

\section{Introduction}

Information and communication technology (ICT) has progressively acquired a prominent role in the educational sector. In higher education, ICT growth has dramatically redesigned the process of teaching and learning (Pulkkinen, 2007; Wood, 1995). As stated by Ghavifekr and Rosdy (2015), ICT integration enables to shift of the traditional teaching methods to a technology-based teaching and learning method equipped with tools and amenities which have links to the use of technologies in any school and university across the globe. Regardless of whether or not Indonesia is a developed country, many students and educators of state Islamic universities throughout Indonesia argue if e-learning amenities are always available. In line with the statement above, Al-Araibi, Mahrin, and Yusoff (2016) claimed that the limitation of the absence of technical aspects is the main hindrance for most higher education institutions. Besides, the condition becomes uncontrollable when COVID-19 strikes. Consequently, educators face difficulties since they have little or no e-learning experience and have not produced any e-learning resources, specifically when operating online platforms (Zaharah, Kirilova, \& Windarti, 2020)

Overall, many state Islamic universities in Indonesia are overwhelmed with various hindrances to using e-learning. The first hindrance came from individual constraints comprising of personal electronic resources, the unfamiliarity of e-learning, IT mastery, and internet package (Alim, Linda, Gunawan \& Saad., 2019; Azhar, 2021; Fauzi \& Asri, 2021; Muhajarah \& Fabriar, 2020; Nisa, Mujizatullah, Idham, Nawawi, Darwis, Amiruddin, Israpil \& Arsyad, 2020; Octaberlina \& Muslimin, 2020). The infrastructures also took part as an issue, including e-learning platforms initiated by the university and electricity outages (Alimron, 2018). Besides, students criticized the way lecturers provided digital content since they demanded interactive and innovative teaching materials (Hartanto, 2018).

The majority of research aims to investigate e-learning barriers were piloted in normal circumstances or before the COVID-19 outbreak, where e-learning is an optional method to improve teaching and learning (Al-Azawei, Parslow \& Lundqvist, 2016; Arinto, 2016; Gamdi \& Samarji, 2016). Besides, many studies have investigated e-learning hindrances during pandemics (Mailizar, Almanthari, Maulina \& Bruce, 2020; Mesiono, 2020; Shahzad, Hassan, Aremu, Hussain \& Lodhi., 2020). In addition, those topics took place in public universities (Al-Azawei et al., 2016; Aldowah, Ghazal \& Muniandy, 2015; Tarus, Gichoya \& Muumbo, 2015). In terms of research novelty, this research provided valuable insights. It was worth investigating since it concerns issues and challenges of using e-learning at a state Islamic university before and during pandemics. This study seeks to find out the primary issues and challenges of using e-learning at one Indonesian state Islamic university and how the participants of the representative university cope with the issues and challenges of using e-learning.

\section{Literature Review}

Many researchers have already investigated and found various hindrances to using e-learning at the tertiary education level, both in international and national contexts. These 


\section{IRJE | Indonesian Research Journal in Education | | Vol. 6| No. 1|June | Year 2022 |}

hindrances below were varied and influenced more by geographical location, political situation, economic constraints, and many more. In the international context, using a quantitative approach, Aldowah et al. (2015) stated that the e-learning hindrances can be categorized into five scopes such as human constraints, financial and physical constraints, technical constraints, and administrative constraints. More specifically, Aboderin (2015) mentioned that the problems include insufficient computers, internet router shortages, inability to access e-learning tools and facilities, expensive software, electricity outages, and many more. Besides, Qureshi, Ilyas, Yasmin, and Whitty (2012) confirmed that one of the major impediments to successful e-learning integration is the lack of electricity. However, they claimed that students' English proficiency also took part as a challenge of using e-learning.

In a national context, the implementation of e-learning faces enormous challenges. By a qualitative approach, a researcher claimed that infrastructure is a long-lasting issue, especially when it comes to e-learning platforms initiated by the university and electricity outages (Alimron, 2018). Besides, the way lecturers provided digital content was also criticized by the students since they demanded interactive and innovative teaching materials (Hartanto, 2018). A previous study conducted by Anggraeni and Sole (2018) showed that e-learning hindrances have something to do with internet access, technical skills, inadequate teaching material designs, and administration support. Regardless of the help from the university, Pratama and Arief (2019) and Chaeruman (2018) remarked that the current e-learning issue stems from students' motivation in terms of their willingness to be accountable for their studies. Besides, other individual constraints such as personal electronic resources, the unfamiliarity of e-learning, IT mastery, and internet packages take part (Alim et al., 2019; Azhar, 2021; Fauzi \& Asri, 2021; Muhajarah \& Fabriar, 2020; Nisa et al., 2020; Octaberlina \& Muslimin, 2020).

\section{Methodology}

\section{Research design, site, and participants}

In this study, the researchers used a mixed method. This study involved three primary groups of informants; 2 faculty boards (the dean and the head of the department of English education), 4 academic staff (i.e., lecturers), and 8 students of the sixth-semester from the English education study program of a state Islamic university in South Sumatra. To sum up, there were 14 participants in this study. Their participation was obtained through the purposeful sampling. In this study, the researchers used their judgments to select the participants expected to provide the data needed to answer the problems of the study (Fraenkel \& Wallen, 2012). Therefore, the participants were selected based on two criteria; (1) those who experienced using e-learning at the representative university for more than one year, (2) those who had good speaking and writing skills levels as they provided information through questionnaires and interviews.

\section{Data collection and analysis}

In this study, two instruments were used such as questionnaires and interviews. There were six main aspects on issues and challenges of using e-learning comprising 


\section{IRJE | Indonesian Research Journal in Education | | Vol. 6| No. 1|June | Year 2022 |}

infrastructure, digital contents, individual constraints, cultural barriers, technical support, and financial support. Additionally, both closed and open-ended questionnaires were to answer research question number one regarding the primary issues and challenges of using e-learning. According to Creswell (2002), along with open-ended type, the closed-ended responses may provide important information and support both concepts and theories in the literature. Besides, it functions as the first instrument before the interview, used to obtain as many follow-up questions (McNamara, 1999). During the interviews, open-ended questions were to get unbiased responses, and closed-ended questions may force participants to respond in a definite way (Creswell, 2002; McNamara, 2009). It should also be noted that there were 12 items in total where 6 closed and 6 open-ended questions, respectively. In the closed-ended questionnaire, the participants needed to choose one of the available options (strongly agree, agree, undecided, disagree, strongly disagree). The items were non-ready-made. It means the questions were made or modified by the researchers. To distribute questionnaires, the researchers used Google Form to collect the data due to the Covid-19 outbreak.

In the interview session, the researchers conducted a semi-structured focus group discussion (FGD) and face-to-face interviews using an open-ended approach with the undergraduate students, academic staff, and faculty boards to answer thoroughly both of the research questions mentioned. Approximately, they were interviewed twice as the researchers had follow-up questions. However, due to the interaction restrictions in the pandemic outbreak, it was conducted online via Zoom platform, voice note via WhatsApp, and audio recorder (for face-to-face interview) with a strict health protocol. Leavy (2017) confirmed that an open-ended interview would allow the interviewees to talk about the issues they think are essential using their languages and describe their experiences in detail with stories and examples. There were 25 questions in total lasting for one hour in one session. It represented fully six aspects on issues and challenges of using e-learning. The interview processes were taken for 4 days, from May 3 to May 6, 2021. The questions were also non-ready-made; that is, made or modified by the researchers. Also, the answers were recorded and eventually be analyzed thoroughly using thematic analysis.

To analyze the closed-ended questionnaire data, the researchers used descriptive statistics in a frequency distribution table form and explained the data from the open-ended questionnaire. Meanwhile, the data obtained from semi-structured FGD and face-to-face interviews were analyzed using thematic analysis, and the recorded interview data in the field were transcribed. To have a safe description and categories of data, the researchers used coding of the interview data. This step involved creating codes to use for data analysis. According to Miles and Huberman (1994), codes are labels or tags of meaning to data and allow the easy identification of segments related to the research questions and any relevant themes. This step was essential for identifying the themes or categories of interview data. Next, the codes were organized around several themes that had been determined. Finally, the researchers conducted analytic interpretations of the interview results of each student's statement that had been systematically collected, categorized, and encoded.

Member checking was to measure the credibility and control of biases in this study. It is the process when the researchers wanted to check the accuracy of the data by returning the report to participants and asking them whether it is accurate or not (Creswell, 2002). In 
addition, the researchers used participants' validation as a technique for exploring the credibility of research data. After sharing all the interview results in a transcript (either in Indonesian or English) to the participants involved, they were asked to affirm whether yes or not the content reflected their perspectives. They were also allowed to comment when the results did not reflect their views, feelings, or experiences. This process aimed to obtain corrective feedback from the participants involved to revise the incorrect data and interpretation for the trustworthiness of this research.

\section{Ethical considerations}

To protect all the confidentiality of the research site and all participants in this study, the researchers masked the university as "University $\mathrm{X}$ " and our participants under pseudonym names (e.g., Student 1, Lecturer 1, Faculty Board 1, etc.)

\section{Findings}

As stated above, the questionnaires were to answer the first research question, which is the primary issues and challenges of using e-learning. Meanwhile, interviews gave additional information for the first research question and thoroughly answered the second research question. Those findings were respectively described below.

\section{Finding from the questionnaires}

To begin with, the findings from the closed-ended questionnaire, as seen in Table 1. would remark and answer the first question (primary issues and challenges of using e-learning) where the participants checked themselves by choosing one of the available options before answering the open-ended items. The options are strongly agree, agree, undecided, disagree, and strongly disagree. If the participants chose either strongly agree or agree, it meant they claimed that there were issues and challenges about the topic. If the participants chose undecided, it meant they were uncertain about the answer. Last, if the participants chose either disagree or strongly disagree, it meant they believed that there were no issues and challenges relating to the topic.

Table 1. Issues and challenges of using e-learning

\begin{tabular}{|c|c|c|c|c|c|c|c|c|c|c|}
\hline \multirow{2}{*}{$\begin{array}{l}\text { Issues \& } \\
\text { Challenges }\end{array}$} & \multicolumn{2}{|c|}{$\begin{array}{l}\text { Strongly } \\
\text { Agree }\end{array}$} & \multicolumn{2}{|c|}{ Agree } & \multicolumn{2}{|c|}{ Undecided } & \multicolumn{2}{|c|}{ Disagree } & \multicolumn{2}{|c|}{$\begin{array}{l}\text { Strongly } \\
\text { Disagree }\end{array}$} \\
\hline & Freq & $\%$ & Freq & $\%$ & Freq & $\%$ & Freq & $\%$ & Freq & $\%$ \\
\hline Infrastructure & 8 & 57 & 6 & 43 & 0 & 0 & 0 & 0 & 0 & 0 \\
\hline Digital contents & 0 & 0 & 4 & 29 & 2 & 14 & 8 & 57 & 0 & 0 \\
\hline $\begin{array}{l}\text { Individual } \\
\text { constraints }\end{array}$ & 2 & 14 & 6 & 43 & 0 & 0 & 6 & 43 & 0 & 0 \\
\hline $\begin{array}{l}\text { Cultures \& } \\
\text { ideologies }\end{array}$ & 0 & 0 & 0 & 0 & 0 & 0 & 12 & 86 & 2 & 14 \\
\hline $\begin{array}{l}\text { Technical } \\
\text { support }\end{array}$ & 0 & 0 & 6 & 43 & 4 & 29 & 2 & 14 & 2 & 14 \\
\hline $\begin{array}{l}\text { Financial } \\
\text { support }\end{array}$ & 1 & 7 & 11 & 79 & 2 & 14 & 0 & 0 & 0 & 0 \\
\hline
\end{tabular}




\section{IRJE | Indonesian Research Journal in Education |}

|Vol. 6| No. 1|June | Year 2022|

From the results of the questionnaires, the researcher also investigated an aspect, namely culture, and ideology. However, it was not an issue or a challenge for the participants. Therefore, only five aspects were hindrances to using e-learning. Based on the information depicted in Table 1 above, more than half of the participants (57\%) strongly agree that the institution's e-learning platform and V-meet (Virtual meeting) are the most significant issues and challenges on infrastructure, followed by Wi-Fi internet access and electronic resources. Most students complained that the platform was terrible and missed many features, including no-editing tools, unavailability of voice notes, and many more. Meanwhile, the rest of the population (43\%) agrees that they are still dealing with power outages and a lack of comfortable classrooms. In addition, the situation worsens when the rain comes, resulting in blackouts and the class carpet and walls getting wet.

Based on the data obtained in Table 1 above, it was assumed that most people (57\%) chose the disagree, describing their lecturers as good and innovative educators. Moreover, the students claimed that the materials shared were interactive, eye-catching, and well served. A few agree $(29 \%)$ since they argue their old lecturers are not technology savvy and cannot visualize the materials. Meanwhile, a couple of respondents $(14 \%)$ were undecided as they believe the lecturers have joined and participated in any webinars, although the majority of academic staff are not supported entirely by the university.

Based on the depiction from Table 1 above, a couple of students (14\%) strongly agree if they have individual constraints comprising of running out of internet packages, spending a high amount of money to buy a SIM (subscriber identity module) card provider, and an internet package, and having technophobia. In addition, nearly half of the participants $(43 \%)$ agree that they are struggling with many hindrances, such as the lack of attention and awareness, time management, personal internet connection package, and the lack of feasible electronic devices used for online learning. Meanwhile, the rest of the sample $(43 \%)$ claimed that they had nothing to do with their individual constraints as they were supported by people and families around them.

Table 1 above also depicts participants' perspectives on technical services provided by university technicians. Nearly half of respondents $(43 \%)$ agree that the university still has a shortage of efficiency in serving students and academic staff and solving e-learning platform issues. Meanwhile, a few people $(29 \%)$ are undecided as they think they have no idea and somehow enjoy the usage of e-learning. On the contrary, a couple of respondents disagree $(14 \%)$, and another pair strongly disagree (14\%), claiming that the technicians are getting better and always helpful in helping when students and lecturers have problems with the university's e-learning or electronic media.

Based on the portrayal from Table 1 above, it is also obvious that most of the participants $(79 \%)$ agree if their university lacks any financial support. They claimed if the university did not support their internet package funds that seemed expensive. Besides, University X only accommodated the students' internet package once or twice through affiliation with the government. The temporary lecturers at University $\mathrm{X}$ also felt the same things; they did not get electronic gadgets and premium Zoom accounts for teaching. Meanwhile, a participant $(7 \%)$ selects a strongly agreed-upon option as her best response to 
the situation since she did not get any internet package fund until now. However, a couple of people $(4 \%)$ are undecided about expressing their attitude.

\section{Finding from the interviews}

The objectives of this study were to highlight the primary issues and challenges of using e-learning at one state Islamic university in South Sumatra and the efforts which the participants reached. In the coding process, the researchers revealed several themes and subthemes as presented in Table 2. It should mention that each of the hindrances in subthemes followed by the efforts was to overcome those hindrances done by the participants.

Table 2. Themes and subthemes

\begin{tabular}{ll}
\hline Themes & Sub-themes \\
\hline Infrastructure & Bad e-learning platform \\
& Inadequate Wi-Fi internet connection \\
& Lack of suitable classroom \\
& Lack of electronic resources \\
& Insufficient electricity supply \\
& \\
& Uninteresting teaching materials \\
Digital contents & Lack of workshops and seminar \\
& Unsupported personal internet package \\
Individual constrains & Unsupported electronic devices \\
& Lack of attention and awareness \\
& Issue on giving direct feedback \\
& Lack of ICT and language skills \\
& Too many tasks \\
Technical support & Bad Services \\
& Bad Management System \\
Financial support & Lack of internet package funds \\
& Lack of electronic resource funds \\
& Lack of premium zoom account funds \\
\hline
\end{tabular}

\section{Infrastructure}

In addition, infrastructure may be seen as the determinant of how developed an institution is. However, University $\mathrm{X}$ is still problematic when it discusses infrastructure, including an e-learning platform, Wi-Fi internet connection, suitable classrooms, electronic resources, and electricity. V-meet (Virtual-meeting) has been a platform used by both educators and students in this university during this pandemic. Nonetheless, many participants found it hard to use and even criticized it.

"V-meet is more terrible. I'm so sorry to say that, but we need speed access and easiness to transfer knowledge." [Lecturer 2, June 6, 2021] 
"I often find a situation that whenever I use e-learning and a lot of people access e-learning, then the e-learning website turns down." [Student 6, Mei 29, 2021]

"When there is a video submission, we cannot upload any videos due to space capacity. Therefore, whenever we have a task, we will use YouTube instead of our e-learning platform.” [Student 4, Mei 29, 2021]

To overcome the hindrances, they can complain directly to the website provided by PUSTIPD (Pusat Teknologi Informasi dan Pangkalan Data). If the students and academic staff still did not get the answer from PUSTIPD, they could go to the crisis center or the study program.

"When you got a problem, just make the complaint by writing it down on the link, and they will fix for you, not in a long time. Within a short moment, they will fix it for you." [Lecturer 4, June 6, 2021]

"If that's the case, you can go to the crisis center or report it to the study program." [Faculty Board 1, June 1, 2021]

Wi-Fi internet connection was the next hindrance; University $\mathrm{X}$ is still catching up with this fundamental amenity.

"Some lecturers from English Education, they find it quite difficult to connect to the Internet.” [Faculty Board 2, June 1, 2021]

"It has a bad connection, especially if the people are crowded." [Student 2, Mei 29, 2021]

"Before the coronavirus pandemic, I always asked my students about the speed of the internet when they used it. They said it's sometimes not bad, ma'am, and sometimes it's very hard to get the access because the students are too crowded." [Lecturer 2, June 6, 2021]

While waiting for improvement from University X, some students found many ways when they could not connect to the internet.

"I totally agree with what all of my friends say about our campus Wi-Fi. It sometimes has a bad connection, so we have to use our own cellular data. In addition, we have to find an Internet provider that the signal is smooth in University $\mathrm{X}$ because the signal is different in each class. In my experience, when we are in PBI 1 class, there is Wi-Fi and Telkomsel is smooth. However, when we go to PBI 3, there is no either signal or Wi-Fi. The Internet provider like IM3 is also the same. Therefore, we have to find the best provider which has decent signal in many classrooms like that." [Student 8, Mei 29, 2021] 
Furthermore, the situation deteriorated when they reported that the classrooms were full and could no longer be used. Regarding classrooms on campus A and campus B, the head of the study program explained,

"It's so difficult to find the room because we have a class from the first semester to the six-semester students regarding the availability of offline classrooms." [Lecturer 4, June 6, 2021]

"I think there are so many broken air conditioners and it affects our e-learning class environment." [Student 1, Mei 29, 2021]

To overcome this issue, the study program's director explained classes on both campuses A and campus $\mathrm{B}$, as seen below.

"To overcome that, we just need to make the schedule until Saturday. However, if we are provided with the classes in campus B too, we will have no problem with the lacks of classes. I think that's what we need to get.” [Faculty Board 2, June 1, 2021]

Besides, University $\mathrm{X}$ is still facing issues and challenges with the lack of tools that it should have.

"At campus A, those things [computers] exist. However, campus B doesn't have them yet." [Faculty Board 1, June 1, 2021]

"For speakers, I think no." [Faculty Board 1, June 1, 2021]

Due to the urgent needs, students sometimes borrow their lecturer's sound speaker to continue learning in offline classes.

"Sometimes, we have to find the speaker as it is hard to find it. Thus, we borrow the lecturers' speaker." [Student 7, Mei 29, 2021]

The electricity in both campus A and campus B were good. However, a blackout might happen anytime since it did not have a generator set.

"In some points, we cannot access the website or everything regarding University X because when there is shutdown from the PLN, so we cannot access anything." [Faculty Board 2, June 1, 2021]

Alternatively, if the blackout occurred when the students had classes, they would go to another building where the electricity network is not the same as each other.

"We will come to the place [another building] with the electricity is on or a place which has good air circulation.” [Student 5, Mei 29, 2021] 


\section{Digital contents}

Regarding this second aspect of issues and challenges of using e-learning, the lecturers at University X still faced difficulties creating a goog teaching materials and having adequate seminars or workshops.

"Sometimes the lecturers give their video presentation for us. However, it is not eye-catching because they are from the old lecturers. Meanwhile, some of the younger lecturers have provided eye-caching and interactive materials." [Student 4, Mei 29, 2021]

"I don't have this kind of issue, but some lecturers might have such that difficulty; they cannot visualize the material into the graphic one. I guess it's an issue." [Lecturer 4, June 6, 2021]

To cope with the problems, the lecturers used YouTube for forming and sharing teaching material.

"You'Tube is also helpful for us to show the guidelines on how to operate any kind of technology or things that we do not know yet." [Lecturer 1, June 6, 2021]

"It was a coincidence for me to use Canva, for example and I find out it was really useful." [Lecturer 4, June 6, 2021]

The lecturers have also questioned the limited numbers of workshops and seminars on e-learning offered by the institution, especially for the temporary DLB lecturers (Dosen Luar Biasa).

"I need more guidance and I didn't get it from the campus." [Lecturer 2, June 6, 2021]

"The university once held workshops to improve lecturers in learning skills. However, it was only limited for at least three lecturers maximum from each faculty. The three lecturers should be able to teach other lecturers the things that they had learned there. However, up to now the three lecturers from Tarbiyah faculty haven't done it yet." [Faculty Board 2, June 1, 2021]

To cope with this issue, the lecturers took individual initiative to join any online webinar.

"I also joined the webinar or workshop. The last workshop that I joined was from $\mathrm{CMO}$ Asia. It is a very good platform for teachers or lecturers. I realized that I need more and I have to increase my knowledge related to the IT on how to bring my class to become more life, more cheerful and my students will not get bored when I'm teaching." [Lecturer 2, June 6, 2021] 


\section{Individual constraints}

This third issue and challenge part outline the kinds of individual hindrances experienced by both students and lecturers which have no link with the facilities or funds from the institution. They are regarding internet connection, lack of electronic devices, attention, awareness, financial problems, etc., which can be seen below.

"The problem is from our students. They are difficult to get the signal from the specific internet provider since most of them live in the remote area." [Lecturer 1 , June 6, 2021]

"It's not only from e-learning but also from our signal and internet quota because the signal can always be strong, smooth, and sometimes very slow." [Student 8, Mei 29, 2021]

As a result, the internet connection problems encountered by students and lecturers were serious and might grow exponentially if not appropriately addressed. To overcome the problem, they did the following ways.

"We have to find Internet provider that the signal is smooth in University X because the signal is different in each class." [Student 8, Mei 29, 2021]

"We share the Wi-Fi." [Student 5, Mei 29, 2021]

The absence of technological gadgets was also one of the main problems, and it challenges students and lecturers face with specific restrictions.

"Sometimes our gadgets or the resources that we have do not support us. Just like me. I have a computer, but my computer somehow doesn't work. Well, that's why I use my phone to teach via Zoom." [Lecturer 4, June 6, 2021]

"But if many applications used will make us confused and my phone memory is full. [Student 8, Mei 29, 2021]

To overcome this hindrance, Student 5 told the solution below.

"I will ask my friends from another university, or I will ask my mother or my sister to lend me the gadget." [Student 5, Mei 29, 2021]

Some lecturers claimed that their students did not follow the subject and catch the essence of the materials by turning off the webcam camera. On the other hand, the students showed their rebuttal that they paid attention during an online class. 
"We do multitasking housework (sweeping the floor, washing the dishes, etc.). We are sometimes just too lazy to put on our hijabs, so we turn off the camera." [Student 6]

"Maybe my connection last week was bad, so I turned off the camera to make it smoother.” [Student 7, Mei 29, 2021]

To cope with this issue, Lecturer 4 would have a quiz to test if the students followed the teaching materials or not.

"I will use quizzes just like open-ended question because you cannot force the students to speak." [Lecturer 4, June 6, 2021]

Besides, students were arguably aware in relation to filling attendance lists during the pandemic outbreak.

"Sometimes I'm typical of person who is easy to forget. If my friends don't remind me filling in the attendance list, I will not check it anymore." [Student 6, Mei 29, 2021]

To overcome the issue above, a lecturer gave a solution.

"Sometimes, some lecturers provide our attendance list from Google form, but it's not all of the lecturers provides it. It's just one or two lecturers do like that." [Student 8, Mei 29, 2021]

Sometimes the lecturers also encountered difficulties giving direct feedback during this pandemic.

"I will use quizzes just like open-ended question because you cannot force the students to speak." [Lecturer 4, June 6, 2021]

Besides, students were arguably aware in relation to filling attendance lists during the pandemic outbreak.

"Sometimes I'm typical of person who is easy to forget. If my friends don't remind me filling in the attendance list, I will not check it anymore." [Student 6, Mei 29, 2021]

To overcome an issue above, a lecturer gave a solution. 
"Sometimes, some lecturers provide our attendance list from Google form, but it's not all of the lecturers provides it. It's just one or two lecturers do like that." [Student 8, Mei 29, 2021]

Sometimes the lecturers also encountered difficulties giving direct feedback during this pandemic.

"The barriers that I have already explained to you are in the matter of giving feedback as many as I can and making sure whether my students can get what I have already explained to them." [Lecturer 1, June 6, 2021]

Regarding this issue, the only thing that students and lecturers did was pray and wait until the government enabled the offline class to give direct feedback to students, as stated below.

"I think we just need to pray a lot. Actually, we just need to get free to go to campus." [Student 5, Mei 29, 2021]

Furthermore, several students and lecturers believed their ICT and language skills are inadequate and require further development from the university.

"In the first semester, we learned about computers. However, we only learn about Microsoft Word, PowerPoint, and Excel.” [Student 4, Mei 29, 2021]

"It seems I lack of language, but not on direct conversation in writing and grammar. I think I have a bad grammar.” [Student 8, Mei 29, 2021]

To overcome it, they did the following ways.

"I like sharing with my friends, especially with those who really I regard as the expert of technology." [Lecturer 1, June 6, 2021]

"I use it to communicate with my friends. Her name is Student 2. I usually call her to improve my speaking and writing. I often use English to communicate with her and we both correct each other if we make mistakes." [Student 6, Mei 29, 2021]

Using e-learning can make college life easier in some cases, but a student claimed that their lecturers assigned them more tasks than in a traditional class.

"When we are using e-learning, the lecturers often give so many tasks to us with a deadline that is too fast." [Student 4, Mei 29, 2021]

In an effort to overcome the problem, they did a following action. 
"Based on my experience, we can discuss with the lecturer to ask for a reduction in assignments or an extension of time to complete the assignments if there are many. But if the lecturer still gives a lot of assignments or doesn't give an extension of time, we still do it." [Student 8, Mei 29, 2021]

\section{Technical support}

PUSTIPD is a university body responsible for managing complaints and maintaining the teaching and learning process. This section emphasizes issues on services and management systems empowered by IT technicians.

"Maybe they got bored, especially when e-learning platform [V-meet] had just been launched at the first time. That's why when I don't know something, or when I talk about something, especially e-learning, I will always contact the technicians." [Lecturer 2, June 6, 2021]

"To be honest, I don't really like them because they are too sensitive. Sometimes, they only contact us using email." [Student 2, Mei 29, 2021]

Those concerned about the unsatisfactory performance offered by the technicians were told to report it through PUSTIPD.

"It has become a helpful unit since they provide as much training to the lecturers to familiarize the e-learning system to all lecturers, and they are open whenever the lecturers have difficulties. So we as the lecturers are free to ask the stops which PUSTIPD provides to ask questions to them. And I believe the response is a bit fast, and they respond to all questions and we are really helpful by that." [Lecturer 1, June 6, 2021]

Besides, some participants complained as whenever a user had a problem, they should fill in the form and frequently check the website to see if the bug had been fixed.

"As far as I know, we can only see the answers just by logging in to the website. I think the IT technician team should link their response towards any issues to the email address of the people who put the complaint in. Therefore, we can also see the answers in the email, because if we do not open the website again after we put in the complaint, we wouldn't know if they have answered our questions or not." [Faculty Board 2, June 1, 2021]

For now, to deal with this issue, students and lecturers or even faculty Boards only may be able to send their complaints on the website provided by PUSTIPD.

"Yes. The lecturers always told us to contact the technicians if something goes wrong on e-learning." [Student 1, Mei 29, 2021] 


\section{Financial support}

This final part of the issues and challenges of using e-learning illustrates the kinds of financial support students and educators mostly complained about, including internet package funds, electronic resource funds, and premium Zoom account funds. Each issue is thoroughly described below.

"Last semester, all the lecturers were told by the faculty or the administrators and they told us to register ourselves to get free data from Telkomsel. Once I tried to register my name, I still didn't get it. I don't know what the reason is and I don't want to ask what happened because it's going to waste my time." [Lecturer 2, June 6, 2021]

"I only got one and it's only 4 GB, and I only need two days to spend it for Zoom class." [Student 6, Mei 29, 2021]

"Because University X does not provide internet package assistance, but the campus has provided it. I think while on campus it can still be used. But when it comes to studying from home, especially now that there are still many students in areas that require them to study online, they have to provide their own extra budget." [Faculty Board 1, June 1, 2021]

In addition to this, the head of the English Language Department also shared the tips for temporary lecturers to buy internet connections from the best SIM provider who offered the lowest prices through educational packages.

"For the internet packages, actually only permanent lecturers who got internet packages or discount. Therefore, for lecturers who doesn't have internet discount, if I am not mistaken every provider has a cheaper price. We just bought for the education stuff. For example, Indosat only costs less than IDR 10,000 to get 30GB. It also for Telkomsel if I'm not mistaken it costs IDR 10,000 if they want to buy the education package. Thus, I think the lecturer doesn't have any problems with the Internet package.” [Faculty Board 2, June 1, 2021]

After an interview with the Faculty Board 1 as the FITK's dean, he also told the writers that the university did not give away or lend electronic resources (laptop, smartphone, and many more gadgets) to students and lecturers during this pandemic.

"No, the FITK does not give away or lend any electronic resources to lecturers and students.” [Faculty Board 1, June 1, 2021]

As an alternative, he suggested students and lecturers allocate their living allowance or transportation budget to buy gadgets to support their teaching and learning during this pandemic, as stated below. 


\section{IRJE | Indonesian Research Journal in Education | | Vol. 6| No. 1|June | Year 2022 |}

"But if you think about it, since this pandemic, previously students paid a boarding house per year, it's best to just switch to buying an internet package with a small amount of money. I think there are pluses and minuses to the impact of this pandemic; even they can help their parents. And their parents also have to realize that they have needs such as internet packages or books that can be purchased online. I think that as long as there is a will and effort, there will be no problem, even parents can save on the budget because it doesn't cost a lot of money. [Faculty Board 1, June 1, 2021]

Using the Zoom as an additional platform after $\mathrm{V}$-meet also became a hindrance for DLB lecturers as the basic version only lasted for 40 minutes.

"If we agreed with using the online class, the university should provide something like the connections. I don't have any unlimited Zoom class for your information. There's 40 minutes time limitation and then the class turns off, so I should begin another 40 minutes to begin my class." [Lecturer 3, June 6, 2021]

However, during the interview session, the head of the study program gave a tip for having a premium Zoom account, as illustrated below.

"Actually, lecturers in University X do not have access to some premium accounts. However, if the students arrange it, they could get a free unlimited Zoom when they registered at the first time, they will also get it when they arranged it for the next class. This is what we usually do. When we need unlimited Zoom accounts, we ask the students to make a new account that previously they register. After that the account was used for at least two times, the students would create another new account. If it's scheduled after the meeting, they will get also unlimited one time if I'm not mistaken. We just do that if the lecturers don't have premium Zoom account." [Faculty Board 1, June 1, 2021]

\section{Discussion}

Infrastructure is debatably the primary issue and challenge of using e-learning, particularly when it comes to the e-learning platform. Mesiono (2020) explained that e-learning is the presence of a system (in the form of software) that manages and monitors interactions between educators and students, both immediate (synchronous) and delayed (asynchronous). By means, the university should keep facilitating the users with high performance and fix the bugs of the platform whether it is in online or offline classes. From the findings, the researchers are in line with Ajadi, Salawu, and Adeoye (2008), who emphasized the importance of internet connection, which enables access to information and resources on platforms intended for educational reasons. Therefore, the participants should anticipate purchasing the internet package. Speaking about the technology era, the researchers demanded to have the basic knowledge to operate the machine, as stated by Qureshi et al. (2012), that the instructors and students of an institution are supposed to have 


\section{IRJE | Indonesian Research Journal in Education | | Vol. 6| No. 1|June | Year 2022 |}

basic skills to utilize e-learning. Besides, the lecturers are supposed to join any academic education and non-academic training (Wang, Liu, \& Zhang 2018). Information and communication technologies (ICTs) have given several methods to make higher education more accessible. However, to accomplish the needed academic goals, their efficient usage necessitates technical knowledge. Every eLearning system develops a basic 'infrastructure' of computers, networks, and communications, as well as a technical department staffed by ICT experts to maintain and improve the infrastructure system, train the users and continuously provide technical support when required by them regularly (Nawaz \& Khan, 2012). Financial support is somehow also seen as the most challenging problem for University $\mathrm{X}$ to have online classes. Insufficient financial support has been identified as another key impediment to e-learning in several studies (Khan, Hasan, \& Clement 2012; Sife, Lwoga, \& Sanga 2007; Tarus et al., 2015). Therefore, the university should pay more attention to the hindrances regarding the funds, or else the problems will grow more exponentially.

This recent study has three limitations. Firstly, two faculty board members (the vice dean 1 and the secretary of the English study program) were excluded from the participants' list due to the hindrance to contacting them during this pandemic. Therefore, the data collection was assumed completed so that the study only needed 14 participants as the sample. Secondly, this research was supposed to use focus group discussion for each participant. However, it used face-to-face interviews (online and offline) due to some participants' errands and time management problems. Thirdly, the IT technicians from PUSTIPD did not contribute to this study since they were not the samples. Therefore, the writer did not further analyze the results regarding issues and challenges in the technical support section.

\section{Conclusion and Recommendations/Implications}

To conclude, University X still encountered many primary issues and challenges of using e-learning. Infrastructure was the dominant major issue that the researcher found, including e-learning platform, Wi-Fi internet connection, suitable classroom, electronic resources, and electricity. Digital content also became another issue for lecturers as they felt it hard to create teaching material content and were dissatisfied with the university's lack of workshops and seminars. The participants also seemed to have many individual constraints with no link to university facilities or funds, such as personal internet connection, lack of electronic devices, lack of attention, lack of awareness, draining data package and battery, giving direct feedback, lack of ICT and language skill, and too many assignments. Besides, technical support (i.e., service and management system) also needed many improvements as the users criticized PUSTIPD performance. Moreover, financial support was also an endless-debated topic that the university should overcome, including internet package funds, electronic resource funds, and premium Zoom account). Regardless of the issues and challenges of using e-learning, it should be noted too here that all participants, such as students, lecturers, and faculty boards, have shown their unique ways to overcome those five hindrances.

From the conclusions above, the researchers of this study would like to give suggestions to those following kinds of professions or institutions. Firstly, for the 


\section{IRJE | Indonesian Research Journal in Education |}

|Vol. 6| No. 1|June | Year 2022|

government of Indonesia, it is suggested that institutions help all universities, including University $\mathrm{X}$ with a large amount of money and free unlimited internet packages for students and lecturers. If that is not possible, the researchers may suggest the country allow face-to-face interaction with strict health protocol at the site since they suffer a lot in the remote area somehow during this pandemic. Secondly, for faculty boards of FITK of University $\mathrm{X}$, it is suggested for the faculty to concern more on students and lecturers (permanent and temporary ones) without exceptions, including financial help allocation to give away free unlimited internet package to maintain teaching and learning process in online classes. At least, to have more affiliations with internet providers so that students and lecturers will get discounts in buying internet package. Thirdly, for lecturers and students, the researchers think they should keep the teaching and learning process, even though it is in the pandemic year, and hope they read this thesis as additional information to cope with primary issues, and challenges of using e-learning.

\section{Disclosure statement}

The researchers declare no conflict of interest in the design of the study; in the collection, analysis, or interpretation of data; in the writing of the manuscript, or in the decision to publish the results.

\section{Acknowledgments}

The researchers' thanks and appreciation to all participants of this study that help them finished the study.

\section{References}

Aboderin, O. S. (2015). The challenges and prospects of e-learning in national open University of Nigeria. Journal of Education and Learning (EduLearn), 9(3), 207-216. https://doi.org/10.11591/edulearn.v9i3.1728

Ajadi, T. O., Salawu, I. O., \& Adeoye, F. A. (2008). E-learning and distance education in Nigeria. Turkish Online Journal of Educational Technology, 7(4). https://files.eric.ed.gov/fulltext/ED503472.pdf

Al-Araibi, A. A. M., Mahrin, M. N. Bin, \& Yusoff, R. C. M. (2016). A systematic literature review of technological factors for e-learning readiness in higher education. Journal of Theoretical and Applied Information Technology. http://www.jatit.org/volumes/Vo193No2/27Vol93No2.pdf

Al-Azawei, A., Parslow, P., \& Lundqvist, K. (2016). Barriers and opportunities of e-learning implementation in Iraq: A case of public universities. International Review of Research in Open and Distance Learning, 17(5), 126-146. https://doi.org/10.19173/irrodl.v17i5.2501

Aldowah, H., Ghazal, S., \& Muniandy, B. (2015). Issues and challenges of using e-learning in 


\section{IRJE | Indonesian Research Journal in Education | \\ | Vol. 6| No. 1|June | Year 2022 |}

a Yemeni Public University. Indian Journal of Science and Technology, 8(32), 1-9. https://doi.org/10.17485/ijst/2015/v8i32/92160

Alim, N., Linda, W., Gunawan, F., \& Saad, M. S. M. (2019). The effectiveness of Google classroom as an instructional media: A case of State Islamic Institute of Kendari, Indonesia. Humanities and Social Sciences Reviews, 7(2), 240-246. https://doi.org/10.18510/hssr.2019.7227

Alimron, A. (2018). Problematika penerapan e-learning dalam proses pembelajaran (studi pada program studi Pendidikan Agama Islam Universitas Islam Negeri Raden Fatah Palembang). Jurnal Pendidikan Agama Islam, 15(2), 199-220. https://doi.org/10.14421/jpai.2018.152-07

Anggraeni, D. M., \& Sole, F. B. (2018). E-learning moodle, media pembelajaran Fisika abad 21. Jurnal Penelitian dan Pengkajian Ilmu Pendidikan: E-Saintika, 1(2). https://doi.org/10.36312/e-saintika.v1i2.101

Aparicio, M., Bacao, F., \& Oliveira, T. (2016). An e-learning theoretical framework. An e-learning theoretical framework, (1), 292-307. https:/ / repositorio.iscte-iul.pt/bitstream/10071/12132/5/24.pdf

Arinto, P. (2016). Issues and challenges in open and distance e-learning: Perspectives from the Philippines. International Review of Research in Open and Distance Learning. 17(2), 162-180. https://doi.org/10.19173/irrodl.v17i2.1913

Azhar, A. (2021). Online Learning amid the COVID-19 Pandemic: A case study of the state islamic university of mataram. Nadwa, 14(2), 265-276.. https://doi.org/10.21580/nw.2020.14.2.6639

Chaeruman, U. A. (2018). Mendorong penerapan e-learning di sekolah. Jurnal Teknodik, 12(1). 025-031. https://doi.org/10.32550/teknodik.v12i1.417

Creswell, J. W. (2002). Educational research: Planning, conducting, and evaluating quantitative (p. 676). Upper Saddle River, NJ: Prentice Hall. http://repository.unmas.ac.id/medias/journal/EBK-00121.pdf

Elrashdi, A. (2021). Using offline e-learning in educational institutions. International Science and Technology Journal, 24. https://www.researchgate.net/profile/Abdelsalam-Elrashdi-2/publication/347852 448_Using_offline_e-learning_in_educational_institutions/links/5fe501a1a6fdccdc b8fbf127/Using-offline-e-learning-in-educational-institutions.pdf

Fauzi, R. A., \& Asri, Y. (2021). Barriers and solutions in online learning during the Covid-19 pandemic, indonesian language education students at the Riau Islamic University. Proceedings of the Ninth International Conference on Language and Arts (ICLA 2020), 539. 14-18 https://doi.org/10.2991/assehr.k.210325.003

Fraenkel, J. R., \& Wallen, N. E. (2012). The basic of educational research. In How to design and evaluate resaerch in education with PowerWeb. http://www.johnlpryor.com/JP_Digital_Portfolio/EDU_7901_files/EDU\%20790 


\section{IRJE | Indonesian Research Journal in Education | \\ | Vol. 6| No. 1|June | Year 2022 |}

1\%20Data\%20Definitions.pdf

Gamdi, M. A. Al., \& Samarji, A. (2016). Perceived barriers towards e-learning by faculty members at a recently established University in Saudi Arabia. International Journal of Information and Education Technology. https://doi.org/10.7763/ijiet.2016.v6.652

Ghavifekr, S., \& Rosdy, W. A. W. (2015). Teaching and learning with technology: Effectiveness of ICT integration in schools. International Journal of Research in Education and Science, 1(2), 175-191. https://doi.org/10.21890/ijres.23596

Hartanto, D. (2018). Pemanfaatan ICT melalui implementasi e-learning berbasis integrasi keislaman dalam proses pembelajaran. Eklektik: Jurnal Pendidikan Ekonomi dan Kewirausahaan, 1(1), 53-71. https://doi.org/10.24014/ekl.v1i1.4804

Hyder, B. K., Kwinn, A., Miazga, R., Murray, M., \& Brandon, B. (2007). The elearning Guild's handbook on synchronous e-learning. The Elearning Guilduild, 20(12), 18771886. https://www.learningguild.com/pdf/4/synchronousbook.pdf

Khan, M. S. H., Hasan, M., \& Clement, C. K. (2012). Barriers to the introduction of ICT into education in developing countries: The example of Bangladesh. International Journal of Instruction, 5(2), 61-80. https://dergipark.org.tr/en/download/article-file/59739

Koohang, A., \& Harman, K. (2005). Open source: A metaphor for e-learning. Informing Science. https://doi.org/10.28945/488

Leavy, P. (2017). Research design: Quantitative, qualitative, mixed methods, arts-based, and community-based participatory research approaches. In BMC Public Health. https://onlinelibrary.wiley.com/doi/epdf/10.1111/fcsr.12276

Mailizar., Almanthari, A., Maulina, S., \& Bruce, S. (2020). Secondary school mathematics teachers' views on e-learning implementation barriers during the COVID-19 pandemic: The case of Indonesia. Eurasia Journal of Mathematics, Science and Technology Education. 16(7). https://doi.org/10.29333/EJMSTE/8240

Mayadas, F. (1997). Asynchronous learning networks: A Sloan Foundation perspective. Journal of Asynchronous Learning Network, 1(1), 1-16. https://doi.org/10.24059/olj.v1i1.1941

McNamara, C. (1999) General Guidelines for Conducting Interviews. Sage, Minnesota. https://web.ics.purdue.edu/ lsnodgra/Site/Project $\% 20$ Links_files/Conducting\% $\%$ $2520 \mathrm{an} \% 2520$ Interview.pdf

McNamara, C. (2009). General guidelines for conducting interviews. Retrieved January 11, 2010. Free Management Library. https://managementhelp.org/businessresearch/interviews.htm

Mesiono. (2020). E-learning management of state islamic university of north Sumatera in pandemic Covid-19. International Journal of Advanced Science and Technology, 29(5). http://repository.uinsu.ac.id/8820/

Miles, M. B., \& Huberman, A. M. (1994). Qualitative data analysis: An expanded sourcebook. 


\section{IRJE | Indonesian Research Journal in Education | | Vol. 6| No. 1|June | Year 2022 |}

sage.theculturelab.umd.edu/uploads/1/4/2/2/14225661/miles-huberman-saldanadesigning-matrix-and-network-displays.pdf

Muhajarah, K., \& Fabriar, S. R. (2020). Menjaga Mutu Pendidikan di Tengah Pandemi Covid-19: Studi Pembelajaran Online di Universitas Islam Negeri Walisongo Semarang. Justek: Jurnal Sains Dan Teknologi,3(1), 42-49. https://doi.org/10.31764/justek.v3i1.3559

Nawaz, A., \& Khan, M. Z. (2012). Issues of technical support for e-learning systems in higher education institutions. International Journal of Modern Education and Computer Science, 4(2), 38-44. https://doi.org/10.5815/ijmecs.2012.02.06

Nisa, K., Mujizatullah, M., Idham, I., Nawawi, M. I., Darwis, D., Amiruddin, A., Israpil, I., \& Arsyad, A. R. (2020). The COVID-19 impact on statistical learning at State Islamic University in East Indonesia. Journal of Physics: Conference Series, 1663(1). https://doi.org/10.1088/1742-6596/1663/1/012051

Octaberlina, L. R., \& Muslimin, A. I. (2020). Efl students perspective towards online learning barriers and alternatives using Moodle/Google classroom during covid-19 pandemic. International Journal of Higher Education, 9(6), 1-9. https://doi.org/10.5430/ijhe.v9n6p1

Pratama, H. F. A., \& Arief, S. (2019). Pengaruh pemanfaatan e-learning, lingkungan teman sebaya, dan motivasi belajar terhadap prestasi belajar. J-PIPS Jumal Pendidikan Ilmu Pengetahuan Sosial), 6(1), 1-12. https://doi.org/10.18860/jpips.v6i1.7811

Pulkkinen, J. (2007). Cultural globalization and integration of ICT in education. Educational technology: Opportunities and challenges, 13-23. http:/ / citeseerx.ist.psu.edu/viewdoc/download?doi=10.1.1.138.6523\&rep=rep1\&t ype $=$ pdf\#page $=15$

Qureshi, I. A., Ilyas, K., Yasmin, R., \& Whitty, M. (2012). Challenges of implementing e-learning in a Pakistani university. Knowledge Management and E-Learning, 4(3), 310324. https://doi.org/10.34105/j.kmel.2012.04.025

Shahzad, A., Hassan, R., Aremu, A. Y., Hussain, A., \& Lodhi, R. N. (2020). Effects of Covid-19 in e-learning on higher education institution students: The group comparison between male and female. Quality and Quantity. 55(3), 805-826. https://doi.org/10.1007/s11135-020-01028-z

Sife, E., Lwoga, T., \& Sanga, C. (2007). New technologies for teaching and learning: Challenges for higher learning institutions in developing countries. International Journal of Education and Development Using ICT, 3(2), 57-67. file://C:/Users/HP/Downloads/article_42360.pdf

Tarus, J. K., Gichoya, D., \& Muumbo, A. (2015). Challenges of implementing e-learning in Kenya: A case of Kenyan public universities. International Review of Research in Open and Distance Learning, 16(1), 120-141. https://doi.org/10.19173/irrodl.v16i1.1816

Wang, Y., Liu, X., \& Zhang, Z. (2018). An overview of e-learning in China: History, 
challenges and opportunities. Research in Comparative and International Education, 13(1), 195-210. https://doi.org/10.1177/1745499918763421

Wood, D. (1995). Theory, training and technology: Part I. Education + Training, 37(1). https://doi.org/10.1108/00400919510079555

Zaharah, Z., Kirilova, G. I., \& Windarti, A. (2020). Impact of corona virus outbreak towards teaching and learning activities in Indonesia. SALAM: Jurnal Sosial dan Budaya Syar-i, 7(3), 269-282. https://doi.org/10.15408/sjsbs.v7i3.15104

\section{Biographical Notes}

SHOHIBUL KAHFI ALAM PUTRA is a graduate student of English Education Study Program, Faculty of Teacher Training and Education, Universitas Sriwijaya.

SOFENDI is a professor in English Education Study Program, Faculty of Teacher Training and Education, Universitas Sriwijaya.

MARGARETHA DINAR SITINJAK is a faculty member of English Education Study Program, Faculty of Teacher Training and Education, Universitas Sriwijaya. 